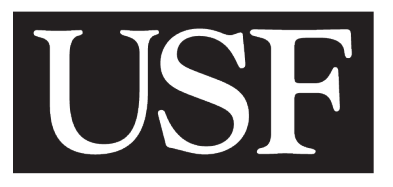

Muma Case Review

A publication of the Muma College of Business | University of South Florida

Volume 6

Number 2

1 APRIL 2020

Sarah Combs

\title{
USF COMMUNITY CRIES FOR RAPID EMPLOYMENT DUE TO COVID-19 DEVASTATING JOB LOSS ${ }^{1}$
}

\begin{abstract}
I never thought that I would have to make a choice between paying my rent and feeding my children. COVID-19 stole my sense of security and has forced my children to worry about things that little kids shouldn't worry about. I have always been able to provide for my family, and now that I've lost my job, I just don't know where to turn. - Gomez, 2020
\end{abstract}

Josie Rocco hung up the phone and wiped away the tears streaming down her face as she contemplated what her next move would be. This was the third call she'd received that day where all she could say was, "I am so sorry to hear that." Words that felt empty with no real solutions or answers attached to them. Josie was the Chief Operations Officer for the University Area Community Development Corporation, Inc. (UACDC), a nonprofit organization dedicated to improving community through resident empowerment and self-sufficiency. Josie was in charge of all the programs and services, and in her 25 years of doing this work, she had never heard such hopelessness in her community's collective voice. The number of residents who had lost their jobs due to COVID-19 was overwhelming. This public health pandemic came out of nowhere, like a thief in the night stealing away security and peace, leaving behind the devastating effects of death, unemployment, loss of housing, and crippling food insecurity.

The UACDC was a 501(c)(3) public/private partnership whose primary focus is the redevelopment and sustainability of the at-risk areas surrounding the University of South Florida's (USF) Tampa campus. It is dubbed "Suitcase City" due to the transient nature of the population, which is plagued with poverty, blight, decay, high crime rates, and a lack of basic resources (Lehigh, Wells, Whiteford, \& Zarger, 2018). Josie hated the fact that the University Area Community (UAC) had been identified as "one of the most economically depressed neighborhoods in Florida," just a few miles from the sixth-largest public university (USF) in the state of Florida (Smith 2014).

Josie knew that additional job loss would not just further cripple this community but send it into depths of despair. She also knew that their current workforce employment program, INVEST, would not be able to handle the countless cries for help that were beginning to bubble up and make their way to her. She leaned back in her chair, closed her eyes, took a deep breath, and cleared her mind. She knew what needed to be done - but how would she launch a new employment program that was geared toward rapid employment in less than a month?

She knew there was a solution - she just had to find it.

\footnotetext{
${ }^{1}$ Copyright (C) 2021, Sarah Combs. This case was prepared for the purpose of class discussion, and not to illustrate the effective or ineffective handling of an administrative situation. Permission is granted to copy and distribute this case for non-commercial purposes, in both printed and electronic formats.
} 


\section{Uptown/University Area Community}

The UAC was located just west of the University of South Florida campus along with other key anchor institutions: Moffitt Cancer Center, Advent Health, James Haley Veterans Administration, and the University Mall. One of the most perplexing questions that Rocco had never been able to answer was, how could there be such health and economic disparities so close to these multi-million-dollar economic engines? The University Area was once a thriving community that hosted the majority of professor and student housing for USF, but in the 1980s that began to change as professors and students left the area, and the duplexes and triplexes that were previously used for student housing were reutilized for Section 8 housing. Due to the transient nature of the community's population, the area was subsequently branded with a name that stuck "Suitcase City." Despite consistent marketing endeavors of the UACDC, this name has found embedding power due to the community being one of the most economically depressed areas in Hillsborough County.

Josie thought about the already overwhelming number of residents living in the UAC that were struggling with a lack of education (32 percent lack a high school education), language barriers, and health problems (e.g., an infant from this neighborhood was twice as likely to die during the first year of life as any other area in Florida; Smith, 2014). These were barriers that even the most successful of individuals couldn't see their way out of alone, and now to add staggering job loss and unemployment rates to the equation was insurmountable.

Josie knew the data. This community was culturally diverse with over 50 percent of residents speaking English "not well" or "not at all," according to the Community Assessment that was done by the UACDC in 2015 (Luckie, 2015). The same study revealed that 9 out of 10 local students at Mort Community Elementary School received free/reduced lunches and that even with their recent addition of a food pantry, shelves were constantly running bare due to food insecurities that plagued the community. Josie served on the Community Advisory Board at Mort and knew the faces of these children. When she heard an individual child's story, it was his or her face that made it real - those faces made this work personal. Establishing these connections wasn't something she did purposefully, it was just how her mind worked. Oftentimes, she wished that these challenges weren't so personal. Josie knew, at that moment, for this new effort to be successful, she must focus on the strengths and opportunities that already exist in this community. That would be the key to creating real and meaningful change.

The UAC was already beginning to transform, progression was happening, and partners were beginning to communicate and work together. Josie's boss, Sarah Combs, would always say that with a community that clearly had such promise, it was just be a matter of time before the potential would be unveiled. "This community is destined for positive change. Nothing short will do." She would not just say it - she meant it. Sarah has been with the organization for 10 years and was the youngest CEO that the UACDC had ever had. She ran the UACDC like a tight ship - focusing on bottom lines, while funding diversification and rich community-based programming with one focused goal: investing the revenue back into the community. Josie never could understand how Sarah continued to re-invent the organization year after year, molding it and shaping it as if it were a living, breathing entity. One of Sarah's greatest strengths was her relationship and trust with the Board of Directors. She had worked hard to hand-select each board member and had even recently changed the by-laws to require that at least one third of the seats (maximum of 19 seats) would be filled by community residents. Having board members who were from the community to give feedback and buy-in didn't just look good on paper, it was a critical aspect of the neighborhood transformation strategy that Sarah created with the help of her colleagues. 


\section{MUMA CASE REVIEW}

\section{The Power of Partnerships}

One of the UACDC Board Members was Mark Sharpe. Mark was a retired Lieutenant Commander for the Navy, had three unsuccessful runs for Congress in the 1990's, and previously served as a Hillsborough County Commissioner for over a decade. Mark now served as the Chief Potential Officer of the Tampa Innovation Partnership (IP) and continued to be well known in the community and business setting. That made him a great partner to solicit in the effort to tackle this wicked problem. In 2011, IP was established by USF to create "a multi-jurisdictional district anchored by globally recognized institutions that would drive economic activity in the area" (Partnership, 2020). Mark joined IP in 2014 and was tasked with forming a coalition of businesses throughout the community. This community sported 4,100 companies that collectively made up a large majority of the area's hiring power, producing more than 74,000 jobs for the Innovation District area. The Innovation District made up 19-square-miles, which has the potential to produce $\$ 11.3$ billion in annual economic impact. Josie knew that Mark would be a great connector to the businesses in the UAC and could make some calls to engage them in the rapid employment program she was seeking to create.

Establishing partnership was the first step, and thankfully, the groundwork had already been done through the building of strong relationships and public commitment. The UACDC had recently been added to IP's Executive Board, which was made up of key anchors in the community. The inclusion of the UACDC represented an intentional commitment that the community would be involved in the redevelopment of the University Area Community, which was inside the Innovation District. A Memorandum of Understanding (MOU) had already been created by the Tampa City Council, Hillsborough County Board of County Commission, IP, USF Board of Trustees, UACDC, RD Management, Advent Health Hospital, and H. Lee Moffitt Cancer Center. This resulted in a commitment of $\$ 2$ million for a comprehensive redevelopment plan for the Innovation District (Perry, 2019). These were the key players that needed to come to the table to orchestrate the financial and political power required to transform and integrate a thriving Innovation District.

The area was rebranded as "Uptown" and one of the core anchors, RD Management, announced its \$2 billion redevelopment plan for long-time struggling community mall that sat in the heart of the district that was now called Rithm. In the 1970s, the University Mall was the "place to be" in Tampa, however, over time, the mall had lost almost every anchor store, leaving thousands of square-feet empty. Immediately after RD Management acquired the property, they announced plans to turn the 100 -acre site into a mixed-use district that would include residential, commercial, and retail properties. Chris Bowen was in charge of the development and spent years in Tampa learning about the community and stakeholders to determine how to best create a mixed-use space that would spark the beginning of change for the area.

"What we're trying to do now is create a framework for all of those players, all of those stakeholders, moving together, both physically, moving from where we have this big tech cluster, and medical cluster and academic cluster, and moving that now to out of their gates, out of their enclaves, and into our neighborhoods," said Chris Bowen, the chairman of the Tampa Innovation (Perry, 2019).

\section{Does a Rising Tide Lift All Boats?}

Josie was aware that while there were some very exciting plans for the UAC, those plans would take time, and redevelopment had a long runway. This left community members with challenges that needed to be 


\section{Combs}

addressed now. There was a part of her that seriously wondered if the redevelopment plans would even help the community. Her fear was that the improvements would just outskirt the community and leave it fallow in its current condition.

John F Kennedy was known for stating that "a rising tide lifts all boats." This purports that when improvements are made generally, that everyone benefits. However, Josie questioned this concept.

The UAC has remained a blighted area stricken with poverty for over thirty years, while the anchor businesses that surround this community continue growing and thriving around it. A perfect example of this is the fence that USF has built around their campus, blocking them off from our community. I think the million-dollar question at hand is, 'Is this going to continue to happen, or is there finally a chance for the UAC to be acknowledged and included in a way that will result in meaningful change for the community?' I feel that displacement isn 't 'if' but 'when' as it is just a matter of time before investors see the opportunity in this community and market it as 'urban renewal.'

This inequality bothered Josie at her core. However, research indicated that inequality is a natural part of a functioning market economy, with economic outcomes reflecting the different efforts and levels of dispersion of incomes and wealth (Waldenstrom, 2009). The issue was indeed complex as the "rising tide" effect could also be detrimental to a community due to wealth disparity. This was seen with the imbalance between the UAC's extreme pockets of poverty and the high wealth found in the community and surrounding areas such as Tampa Palms, where the average household income was \$105,113 ("Point 2: Tampa Palms Demographic") and Avila, an affluent neighborhood in North Tampa that was considered to be one of the most coveted and exclusive communities in Tampa.

Sarah Combs, CEO of the UACDC, said in an interview with The USF Oracle that she shared these concerns and had identified strategies to move forward. Employment opportunities fell short, and many residents lived below the poverty line, while crime and public safety were long-standing issues (Sweet, 2020).

While these new changes are cause for hope, they also raise concerns about displacement. As the community adds infrastructure and businesses, it raises property values, potentially driving up rents in the surrounding neighborhood. We definitely want to make improvements to the community but not at the cost of residents.

\section{Community Quarterback}

Josie had joined the UACDC nearly seven years before and immediately knew that there was something special about this organization. She had worked at several nonprofit agencies before, but none of them had what the UACDC had. It was hard to describe the feelings she felt when she came to work every day. She sensed that she was made for the position. She was engaged in the mission and truly found passion in the work she was doing. The University Area Community Development Corporation, Inc. (UACDC) was established in 1998 as a public/private partnership designated as a 501(c)(3) non-profit organization. It was created by the University of South Florida Area Community Civic Association (USFACCA), in collaboration with the Hillsborough County Weed \& Seed Initiative Committee. The UACDC was established to bring public and private sectors together to revitalize one of Tampa Bay's most blighted communities. At UACDC, Josie and her team played an important community role as they didn't only oversee the activities and programs for residents but they also provided a stable, neutral environment in which stakeholders could interact and collaborate. 
UACDC had a 22-year-long history operating on a budget just shy of \$6 million with 55 staff members scattered throughout the four programming centers in the community. The organization created two endowments totaling over $\$ 1$ million and had a healthy balance sheet due to their diversification efforts. Their portfolio included property, housing, and cash (Exhibit 1 - UACDC Statement of Financial Position, 2019).

The UACDC had evolved into an organization that has been embedded into every fiber of the community. It continually worked to study and learn about its community's traumas, fears, and areas of weakness while also searching for its strengths. What made the UACDC different from other non-profit organizations was their successful ability to organically craft programs and services through engaging with residents and following through with promises. Josie had direct oversight over a wide range of holistic program services that had the power to move people out of poverty intentionally and permanently.

Josie had always had a strong desire to advocate for the underdog, and that might be because she was once considered an underdog herself having become pregnant at 16 and feeling as if the world was closing in - she knew what it is to need a hand up. Josie had been through some defining struggles in her life but had always held to her belief that people should be given equal opportunity to thrive. Josie's grandkids called her MiMi, and a stop by her office might result in a quick game of face-time peek-a-boo with 2-year-old Madalyn. Josie had strong family values and an even stronger work ethic - both of which allowed her to thrive in her position as COO. A stop by the facilities team break room might land you an upbeat conversation with Josie, and if you were lucky, a slice of her home-cooked breakfast casserole. Positivity, love, and acceptance were the main ingredients that allowed Josie and her team to tackle the social inequity present in a community that hosted an 80 percent minority population and extreme poverty (Exhibit 2).

\section{Health Disparities of Low Income, Communities of Color}

One morning, Josie walked into a meeting where she found her boss Sarah with her voice raised high on the phone, making large arm movements while she strongly voiced her opinion to whomever was unlucky enough to be on the other end. Sarah had been talking to Hillsborough County Code Enforcement regarding their lack of enforcement at one of the apartment complexes that was located across the street from the Harvest Hope Park (UACDC's private park that they were building). The water conditions, due to the contaminated well, were so severe that mothers were complaining that their children were contracting urinary tract infections while bathing. UACDC had coordinated with the Department of Health who conducted water quality tests that resulted in high levels of lead and chlorine. For low-income communities and communities of color, this was a fairly common challenge due to the lack of infrastructure for water and sewer, which forced residents to access wells for water and unsanitary septic systems for sewer (Smith 2001).

Josie waited for Sarah to finish the call, knowing exactly why she was so frustrated. Josie had learned about the health risks during a yearly community conversation where parents disclosed how they had to search public locations for showers (including the UACDC community center's showers, which were only open for gym membership). Mothers said that they were paying the $\$ 5$ monthly membership fees just to access the showers and be able to safely bathe their children. That morning, ABC Action News WFTS Tampa Bay aired a news story titled "University Area CDC says contaminated water gave children UTIs, flooding caused ringworm." 


\section{Combs}

"We've found that residents in this community are really complaining about the quality of water in the community. What we've found is that a lot of those residents are on well water that's contaminated. That's just something that no mother should have to go through. We really feel strongly that this kind of health issue is not acceptable in this area and we're really working hard to ensure that we can make needed infrastructure improvements to be able to mitigate that," said University Area CDC CEO Sarah Combs (Exhibit 3).

It was in situations like these that Josie immediately thought of how she would feel if it were her daughter who lived in those apartments. She visualized how she would feel if her granddaughter Madalyn was one of those children who had to go to the closest community center to shower. She would be furious and would demand change. But she knew better than anyone that the kind of infrastructure change that was needed would cost millions of dollars and take years to advocate for, prior to funding being earmarked. This was exactly what the UACDC would do. Josie knew that Sarah had her mind made up and would gather just the right amount of support from the Board of County Commissioners and the City Council to address these health disparities.

Not only did the UACDC create a task force to address the lack of infrastructure found in the UAC, the UACDC took it one step further and wrote an Environmental Protection Agency Assessment Grant for $\$ 300,000$ to clean up contaminated properties and develop community projects. Josie was quoted in the WUSF news as saying that she hopes the grant will bring "love, light, and hope" to the University Area community during the awards ceremony (Exhibit 4). Hope was a word that was known in the community. Josie knew that hope was important to this community. Sometimes hope was all they had.

\section{COVID-19 Job Loss}

Due to COVID-19, residents were losing their employment rapidly, and after pulling some statistics, Rocco learned that the Hillsborough County Economic Development was predicting the unemployment would soar to over $25 \%$. One in four working residents was losing their employment, and to make matters worse, most were unable to even seek unemployment assistance due to high demand and weak internal systems. According to the Tampa Bay Times, the State Department of Economic Opportunity's overwhelmed unemployment website blocked untold numbers of laid-off workers from filing unemployment claims (Danielson, G. B. a. R.).

To illustrate the magnitude of this specific challenge, in a two-week period, 6 percent of American workers, nearly 10 million people, applied for unemployment benefits. The state of Florida alone reported 226,999 unemployment claims at the end of March 2020, which was triple the amount from the previous week (Exhibit 5). If unemployment numbers continued to rise, economists were predicting that it wouldn't be long until the United States would enter an economic recession.

Bill Copeland was one of those statistics. Bill had worked as a landscaper in the UAC and made a good living to support his wife and three children. When Bill lost his job, he knew he only had a month or so before they would be in trouble. Like most members of the community, Bill and his family lived paycheck to paycheck (Friedman, 2019). Bill knew that he needed to file for unemployment right away so that he could receive benefits before the situation became desperate. Like most residents who lived in low-income communities, Bill was affected by the great digital divide and didn't have internet in his home. Bill learned from a neighbor that paper applications were being provided at the University Area Community Library. After mailing his application and waiting several weeks with no response, Bill decided to use a friend's computer and try that route as he knew he could wait no longer.

"Every day I call their offices to check the status of my application - and nothing. No one answers the phone or calls you back. With COVID-19 shutting everything down, it's like they shut 
down too. They don't realize how many families are depending on these benefits until they find another job. We are talking about essentials - food and shelter. I am starting to feel desperate," said Bill Copeland.

Residents were losing their employment at an alarming rate, and the weight of true fear was weaving its way through the community. This was the kind of fear that paralyzes you - covering you with a veil of desperation. It was with the realization of this that Josie truly understood what was at stake. She could feel the wave of uncertainty in the air. Josie, herself, began to think of her own health and how getting this virus could compromise her already challenged respiratory system. And what about her aging father who lived in an assisted living facility? The challenge was more than either professional or personal - it was both. Josie knew she would have to look at this challenge differently to be successful. How would an already vulnerable community be able to cope with this kind of devastation? Could social distancing and isolation force companies to create new jobs, and would those jobs be a good match for low-income residents? What would the secondary effects of job loss be on housing, mental and physical health, access to food, domestic violence, and crime? Could a rapid employment program make a difference against the odds that were stacking up, or should Josie be focusing on something else - something more important?

Rocco immediately rallied a focus group to examine all angles of this complex challenge that was growing by the day. The CEO, Sarah Combs was the first one to be briefed and from there, like a welloiled machine, the Executive Committee of the Board was summoned and briefed on the challenges that the community was facing, specifically the unemployment status. Sarah, like any strategic CEO, made it known that before any next steps were taken, the board had to be engaged and supportive; they had to be willing to be nimble, minimize red tape, and do what it takes to meet the needs of the community immediately.

\section{Creation of INVEST Workforce}

In 2014, the UACDC turned one of their office spaces into a computer lab out of a direct response from the community. Through community conversations, the UACDC learned of the residents' need to be able to have access to computers and internet to apply for resources, benefits, conduct job searches, and other digital needs. The community did not have a library or any other resource for residents, so the UACDC made the decision to create a computer lab. This provided a solution to the digital divide that plagued the community. After a year operating the computer lab, it was apparent that the community needed more than just a computer lab - they needed a program designed to give residents access to the training that would help them secure employment. This realization is what led to the creation of INVEST.

The INVEST Workforce Program was created in 2015 and designed to assist individuals with obtaining the knowledge and skill sets needed to achieve self-sufficiency. Since its inception, the program has served over 7,500 individuals and focused on the development of employability skills through soft-skills training and a host of other supports. One of the main objectives of the program was teaching participants how to access resources and remove the historical barriers often found in low-income, marginalized communities, including lack of transportation and childcare, among many others. While the INVEST program was successful in meeting its desired outcomes and objectives, the UACDC strongly believed that the community deserved to have a place where residents could access more of these resources, so they began their efforts to advocate for a community library. Those efforts paid off as the Arthenia L. Joyner University Area Community Library broke ground in 2017. In 2018, a state-of-the-art media library was added (Exhibit 6). 


\section{Combs}

\section{INVEST Workforce Certification}

In 2019, the UACDC conducted 1,810 job searches, provided 160 Microsoft Office certifications, and hosted 25 training sessions, as well as two job fairs to assist nearly 2,000 University Area residents in improving their employment readiness and status. Having a community library just a block away from the UACDC was the perfect opportunity to make a pivotal shift in the programming model. This shift included specific industry training, on-the-job training, and job placement through the creation of strong employer partnerships. By expanding the program with training and certificate programs that were in high demand in the immediate area, coupled with creating employer relationships, the UACDC was able to create a pipeline of entry-level job placements. The three occupation certificate programs were selected based on Career Source projections for Hillsborough County during 2015-2023, using Florida Labor Market Statistics (Exhibit 7).

\begin{tabular}{|l|l|}
\hline \multicolumn{1}{|c|}{ Occupation Certificates } & Average Job Openings \\
\hline Certified Nursing Assistant & 254 \\
\hline Landscaping Maintenance \& Groundskeeper & 267 \\
\hline Custodial Technician & 312 \\
\hline
\end{tabular}

The program followed a Workforce Development Model that helped to ensure a high level of workforce development comprehension using a system of assessment measures, experiences, trainings, education, access to resources, and networking. When a participant entered the program, they were assessed on their level of workforce experience and given the opportunity to complete industry certification in one of the three areas listed above: Healthcare, Landscaping, and Custodial. Participants moved along the continuum in a direction and pace appropriate with their circumstances, learning style, ease of understanding, and other individual factors. The goal of the program is to have individuals earn their certification and be placed into employment within the timespan of eight weeks (Exhibit 8).

INVEST Workforce provided enrolled individuals with support to cover the costs of training in the areas that met employer-driven skill needs and participant interests and abilities. These certifications provided career pathways and academic success for individuals who aspired to a career in a chosen profession. Additionally, short term training and stackable credentials led to ongoing development and wage increases over time. Training ranged from one week to four weeks, depending on the program. INVEST Workforce targeted healthcare careers with a primary focus on Certified Nursing Assistants (C.N.A.s), and other in-demand healthcare occupations. Other certifications include Green Industry Best Management Practices (GI-BMP) certification for lawn-care specialists and industry-standard ISSA (the Worldwide Cleaning Industry Association) certified facilities/custodian technicians.

Thanks to the investment and partnership of the Fifth Third Foundation, the UACDC was able to gain access to NextJob software, which was a custom job club curriculum. This advanced technology included resume building, interview skills, the first 90 days on the job, and other supportive soft-skills that were needed to ensure a candidate was ready for employment. NextJob was a perfect match for INVEST Workforce and came with monthly technical phone calls to establish a support group for targeted individuals who were unemployed to connect them with additional resources through their job search. In addition, the UACDC set up a text messaging service as a communications vehicle to ensure that residents had a pathway to stay connected.

\section{Rapid Employment}

Josie was proud of the INVEST Workforce program that the UACDC had created but knew that a more intentional focus was needed to get residents back to work as soon as possible. Rapid employment was what was needed to solve the immediate challenges that the community was facing for those residents who were already previously in the workforce, skilled, and trained, but laid off or furloughed due to COVID-19. Rapid 


\section{MUMA CASE REVIEW}

employment would need to focus on identifying those residents, assessing their skills and knowledge, and matching them with local employers who were hiring - all done at lightning speed. This endeavor, to Josie, was the thing that could make the difference for a family and get them back on their feet.

"I have worked since I was 12 in my Abuela's bodega, stocking shelves and sweeping the floors. My grandmother taught me that if I worked hard and always did the jobs that no one else wanted to do, that I would stand out. That lesson has helped me in every job that I have had, especially in the cleaning business, which is what I do now. When my boss needs a job done right, she always goes to me.

When COVID-19 hit, people weren't staying at hotels anymore, so my boss couldn't keep all of the workers, and I was laid off. I am a single parent raising two children, and not having income has been hard, but the hardest part for me is the fact that I feel like I am letting my family down. I hit my lowest point when I had to ask my Abuela for money to pay rent this month. I never thought that I would have to depend on someone else to keep a roof over my children's heads. I need a job and am willing to do anything. If I could just find a job, I could say that there is still hope," said Margarita, a UAC Community member.

Employment was more than just bringing in a paycheck every couple of weeks to pay the bills. While that was important, it went much deeper than that. For most people, having a job was a direct reflection of themselves. It showed that they can support their families and contribute to society in a meaningful way. When a job was taken away, especially suddenly, it turned an individual's life upside down and began to affect every aspect of their life in a negative way. The faster employment can be re-established, the less impact and trauma a family will experience.

Charles, another community member shares "This morning, my wife and our three boys left to go up north to stay with my wife's parents. I never imagined that I would ever be in a position where I had to separate my own family in order to survive. I lost my job a month ago due to being furloughed, and the small savings that we did have went fast, leaving me with no choice but to send my family up north where I knew they would have a safe home to sleep in and three meals a day. I didn't want my family to see us get evicted or get to the point where they saw no food in the fridge, so I wanted to send them away before that happened. I am desperate for a job, and the sooner I can get a job and get some income coming in, the sooner I can bring my family back. I will do anything. I can't let my family down,"

\section{The Decision}

Josie identified several avenues to resolve the dilemma that focused on getting individuals with barriers to employment hired during COVID-19, but which one is the right one? The critical importance of choosing the "right" option weighed on Josie as she pondered which direction the organization should go. One thing was certain: Residents needed employment immediately, which meant that a decision needed to be made now. Josie considered five options. The question was, which option will lead to the solution her community needed?

1. Do nothing.

2. Keep the INVEST Workforce program the same, only adding information and assistance to help residents file for unemployment and seek out other resources. 


\section{Combs}

3. Redesign the INVEST Workforce program to be geared toward rapid employment, targeting local companies who were hiring (both essential positions and virtual positions), matching them with qualified residents for employment.

4. Launch a new program geared toward rapid employment while also running INVEST

Workforce. Secure new funding sources quickly and hire new staff to create systems and run the program.

5. Partner with an organization that was already specializing in rapid employment and collaborate with them to provide their needed service to the University/Uptown Area community (if a partner exists that is willing to specifically focus on the UAC). 


\section{MUMA CASE REVIEW}

\section{References}

Bakst, A. (2019, June 13, 2019). EPA Grant Brings Development Hope to Three Tampa Area Communities. WUSF Public Media. Retrieved from https://wusfnews.wusf.usf.edu/post/epagrants-bring-development-hope-three-tampa-area-communities

Danielson, G. B. a. R. (2020, April 2, 2020). Coronavirus unemployment crisis deepens in Florida and U.S. Tampa Bay Times. Retrieved from https://www.tampabay.com/news/business/2020/04/02/coronavirus-unemployment-crisisdeepens-in-florida-and-us/

Friedman, Z. (2019, January 11, 2019). 78\% Of Workers Live Paycheck To Paycheck. Forbes. Retrieved from https://www.forbes.com/sites/zackfriedman/2019/01/11/live-paycheck-to-paycheckgovernment-shutdown/\#2ade32244f10

Lehigh, G., Wells, E. C., Whiteford, L. M., \& Zarger, R. K. (2018). Capacity building, environmental justice, and brownfield redevelopment : a case study of Harvest Hope Park, Tampa Bay, FL: University of South Florida.

Luckie, B. (2015). University Area Community Needs Assessment.

Partnership, I. (2020). Retrieved from https://tampainnovation.com/discover-the-ip/

Perry, M. (2019, December 19, 2019). The City of Tampa Buys Into Innovation District in North Tampa. Spectrum Bay News Nine. Retrieved from https://www.baynews9.com/fl/tampa/community/2019/12/19/the-city-of-tampa-buys-intoinnovation-district-in-north-tampa

Point 2: Tampa Palms Demographic. Retrieved from https://www.point2homes.com/US/Neighborhood/FL/Hillsborough-County/Tampa-PalmsDemographics.html

Scott, L. (2020, February 3, 2020). University Area CDC says contaminated water gave children UTI's, flooding caused wringworm. ABC Action News WFTS Tampa Bay. Retrieved from https://www.abcactionnews.com/news/region-hillsborough/university-area-cdc-sayscontaminated-water-gave-children-utis-flooding-causedringworm?fbclid=IwAR2WcM9MSjsluEJK006ZA8ErbTQtPm11xpS4iX78YfahAbhOkMBIVFA $\underline{8 \mathrm{dps}}$

Simply, C. (2020). Retrieved from https://www.collegesimply.com/colleges/rank/colleges/largestenrollment/state/florida/

Smith, P. B. a. W. (2001). Improving Access to Infrastructure Services by the poor: Institutional and Policy Responses. World Bank.

Smith, W. (2004, April 7, 2004). Hit and Run Wounds Neighborhood. Orlando Sentintel, p. A6.

Sweet, N. (2020, January 26, 2020). USF Area Neighborhoods Needs Development without Displacement. The Oracle. Retrieved from http://www.usforacle.com/2020/01/26/usf-arearedevelopment/

Waldenstrom, D. (2009). Lifting All Boats? The Evolution of Income and Wealth Inequality over the Path of Development. (Doctorate Doctoral Dissertation). Lund University, Media-Tryck. (978-91-6287924-2) 


\section{Acknowledgements}

Special acknowledgement to the UAC residents for allowing the author to share their personal stories. Special thanks to the UACDC and the protagonist Josie Rocco for allowing the author to share their stories. The University Area Community Development Corporation, Inc. retains the rights to the intellectual property highlighted throughout and authorizes the author for use in this publication. Specific language acknowledging the following programs: UACDC Workforce INVEST program, UACDC Neighborhood Transformation Strategy. This case study is based on work supported by the following partners/funders; EPA Brownfield Area-Wide Planning Grant, Hillsborough County Economic Development, Fifth Third Foundation, Tampa Innovation Partnership and University of South Florida Brownfield Center.

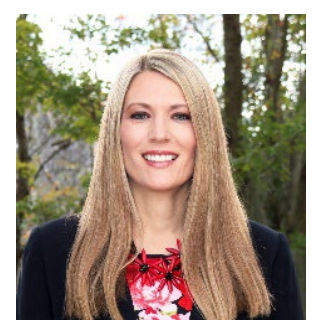

\section{Biography}

Sarah Combs is the Chief Executive Officer of the University Area Community Development Corporation, Inc. Combs joined the organization in 2010, and under her senior leadership the organization has more than tripled the number of children and adults it reaches with education, health, workforce, cultural arts and other programs. With more than 18 years of experience in the nonprofit sector, Combs' experience spans nearly every facet of organization from program development to real estate. Combs previously served as the Chief Operations Officer for the UACDC and has been with the organization for over 10 years. Combs was born and raised in Colorado and moved to Tampa over 15 years ago to raise her daughter and identical twin boys with her husband Will. Sarah's main focus is on the holistic redevelopment of the Uptown University Area Community where she is currently leading the community's neighborhood transformation strategy as an effort to stabilize the community and prevent gentrification. 


\section{Exhibit 1: UACDC's Statement of Financial Position}

University Area Community Development Corporation, Inc. and Subsidiaries

Consolidated Statement of Financial Position

September 30, 2019

(With Comparative Totals for 2018)

20

2018

19

Assets

Cash and cash equivalents

Accounts receivable, net

Prepaid expenses

Beneficial interest in assets of community foundation

Property and equipment, net

Other assets

$\begin{array}{rr}\text { \$ 2,509,942 \$ } & 3,291,466 \\ \mathbf{1 , 2 6 3 , 4 2 3} & 621,359 \\ \mathbf{1 1 1 , 3 7 3} & 134,424 \\ \mathbf{6 7 3 , 6 6 0} & 657,462 \\ \mathbf{6 , 9 6 1 , 2 2 7} & 6,281,812 \\ \mathbf{1 , 1 8 0} & 1,180\end{array}$

Total assets

$\$ \mathbf{1 1}, \mathbf{5 2 0}, \mathbf{8 0 5} \$ \quad 10,987,70$

\section{Liabilities and net assets \\ Liabilities: \\ Accounts payable and accrued expenses \\ Deferred revenue}

Without donor restrictions

With donor restrictions

Commitments and contingencies (Note 10)

Net assets:

$$
\begin{array}{rr}
\$ \mathbf{5 3 7 , 6 0 6} & \$ 323,789 \\
\mathbf{2 0 4 , 3 1 4} & 164,356
\end{array}
$$

Mortgages payable $\underline{2,474,688} 2,474,688$

Total liabilities $3,216,608 \quad 2,962,833$

Total net assets $\underline{8,304,1978,024,870}$

Total liabilities and net assets $\$ 11,520,805 \$ 10,987,703$

See notes to consolidated financial statements. 


\section{Combs}

\section{Exhibit 2: Demographics of University Area Community}

Table 1. Demographic Characteristics of the Project Area in Regional Context.

\begin{tabular}{lllll}
\hline & Project Area $^{\text {i }}$ & City $^{\text {ii }}$ & County $^{\text {iii }}$ & State $^{\text {iv }}$ \\
\hline Population & 25,600 & 376,345 & $1,378,883$ & $20,598,139$ \\
Per Capita Median Income & $\$ 14,000$ & $\$ 34,570$ & $\$ 31,173$ & $\$ 30,197$ \\
Percent Minority & $80 \%$ & $54 \%$ & $27 \%$ & $22 \%$ \\
$\quad$ African American & $35 \%$ & $24 \%$ & $18 \%$ & $17 \%$ \\
$\quad$ Hispanic & $44 \%$ & $25 \%$ & $28 \%$ & $25 \%$ \\
Age $>65$ & $8 \%$ & $12 \%$ & $13 \%$ & $20 \%$ \\
Age $<17$ & $26 \%$ & $21 \%$ & $23 \%$ & $19 \%$ \\
Unemployment & $9 \%$ & $3 \%$ & $4 \%$ & $4 \%$ \\
Poverty Rate & $38 \%$ & $19 \%$ & $15 \%$ & $13 \%$ \\
No HS Diploma & $30 \%$ & $7 \%$ & $7 \%$ & $7 \%$ \\
No Vehicle & $31 \%$ & $10 \%$ & $6 \%$ & $6 \%$ \\
Renter Occupied Housing & $89 \%$ & $52 \%$ & $41 \%$ & $35 \%$ \\
\hline
\end{tabular}

1 EPA EJ Screen ACS Tool:

1 US Census 2014-2018 ACS 5-Year Data Profile

1 US Census 2014-2018 ACS 5-Year Data Profile

${ }^{1}$ US Census 2014-2018 ACS 5-Year Data Profile

Source: EPA EJ Screen ACS Tool, US Census 2014-2018 ACS 5-Year Data Profile 


\section{University Area CDC says contaminated water gave children UTIs, flooding caused ringworm}

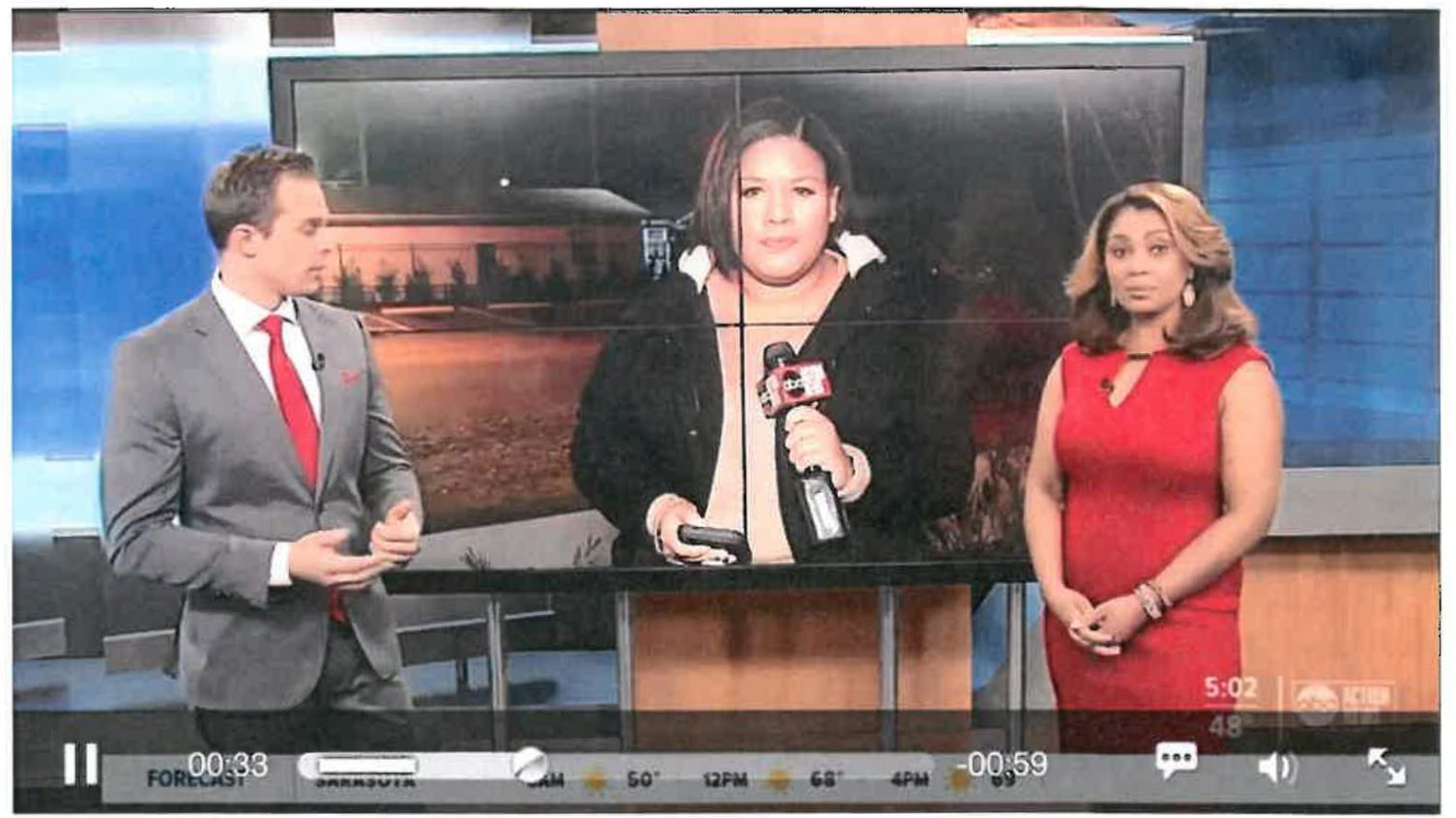

A new effort to fix major infrastructure issues in the University Area neighborhoods near USF is revealing health concerns. Story: https://wfts.tv/2Opihqq

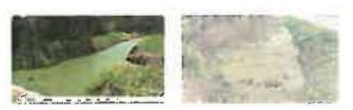




\section{Combs}

HILLSBOROUGH COUNTY, Fla. - - A new effort to fix major infrastructure issues in the University Area neighborhoods near USF is revealing health concerns.

"We've found that residents in this community are really complaining about the quality of water in the community. What we've found is that a lot of those residents are on well water that's contaminated," said University Area CDC CEO Sarah Combs.

Conditions at one apartment complex were so bad that mothers complained they couldn't bathe their children without the water giving them urinary tract infections.

The University Area CDC learned about the health risk during a series of community meetings where parents told them they had to take their children elsewhere for baths.

"We learned through testing of the water that there was high chlorine and high lead and it was very unsanitary," said Combs.

After citations, the landlord sold the property. It now has a new owner who fixed the problems, but the UA CDC says this is just a small example of what's happening throughout the area.

"That's just something that no mother should have to go through," said Combs.

\section{HILLSBOROUGH NEWS | The latest headlines from Hillsborough County}

"We really feel strongly that this kind of health issue is not acceptable in this area and we're really working hard to ensure that we can make needed infrastructure improvements to be able to mitigate that," she added.

The UA CDC is working with both the City of Tampa and Hillsborough County to begin to fix the problems.

The redevelopment in the University area is one of the largest projects in the state.

"We're talking about sewer and water and lighting and sidewalks. Those things that are critically important in order to build a livable community. They have to be addressed first," said Combs. 


\section{MUMA CASE REVIEW}

When the UA CDC began acquiring property it realized there were issues with water and sewer in throughout the neighborhood.

"We found that a lot of the properties that we are seeking out don't have access to water or sewer so in order to build on that we're going to have to put in septic which is just not a good option for any resident in the community," said Combs.

The group also purchased a property with major flooding issues and huge trenches filled with water that pose safety risks for children. It's working with the EPA to figure out how it can fix the property.

The infrastructure issues are limiting progress.

The UA CDC says most properties are in poor condition.

"Being able to really try to figure out how do we improve those conditions so families aren't living in homes that have mold spores the size of your hand and roofs that are falling in. We really have to address those issues in order to ensure that we have a fair and equitable community," said Combs.

\section{RECOMMENDED: Harvest Hope Park opens in Tampa's University Area}

The organization is currently working to bring together community stakeholders, government officials and agencies to figure out how they can work together to improve the area one block at a time.

The UA CDC is also looking for grants to make improvements.

The group just started a new working committee about three months ago with the City of Tampa to find out how widespread the infrastructure issues are.

However, the organization says the problem is so bad it, it needs a lot of help from the community.

"We're looking for any engineers or anyone that would be helpful in volunteering your time and helping us really figure out the scope of the problem in the community. More hands are better than one and we're stronger together than we are apart," said Combs.

(Scott, 2020) 


\section{Combs}

\section{Exhibit 4: EPA Grant}

\section{EPA Grants Bring Development Hope To Three Tampa Area Communities}

BY CARRIEPINKARD UPEOPLE/CARRIE-PINKARD) \& ADAM BAKST (UPEOPLE/ADAM-BAKST) • JUN 13, 2019

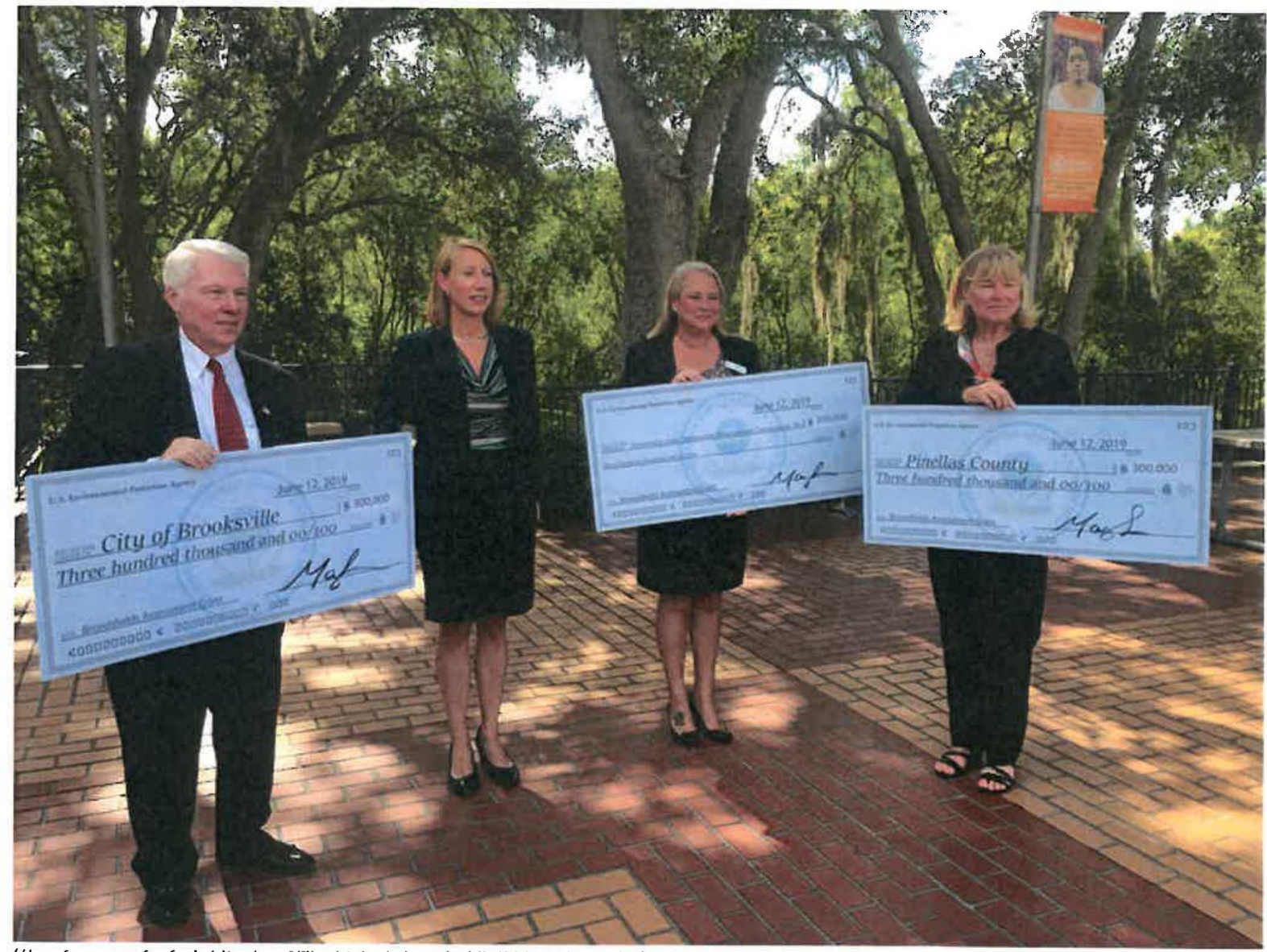

(//wusfnews.wusf.usf.edu/sites/wust/files/styles/x_large/public/201906/Grant.jpg)

William Kemerer, Pat Gerard, and Josie Rocco accept checks on behalf of Brooksville, University Area in Tampa, and Pinellas County. ADAM BAKST/WUSF PUBLIC MEDIA

Three Tampa Bay area communities will be able to make improvements thanks to their share of almost a million dollars in grants from the Environmental Protection Agency.

The Lealman community in Pinellas County, the University Area in Tampa, and the city of Brooksville will each receive $\$ 300,000$ to clean up contaminated properties and develop community projects. 
MUMA CASE REVIEW

Representatives from the three communities came to the University Area Community Center in Tampa to receive their checks Wednesday.

Brooksville Mayor William Kemerer was delighted that his small city of 8,000 residents was selected by the EPA.

The southwest entryway into the Hernando County city was last used in the mid twentieth century, when it contained gas stations and auto repair shops. The mayor said environmental experts believe the ground there contains contaminants and possibly buried gasoline tanks.

"This will now provide us with the opportunity to go in there and evaluate the entire area," he said. "We can understand what's underground there and what contamination may or may not be there."

After the land is cleared of contaminants, the city will try to partner with private landowners to develop the area.

University Area Community Development Corporation COO Josie Rocco said a portion of their grant will go toward developing a cultural center. According to Rocco, it will serve as a hub for the community and will feature a garden, seven-acre park, and classrooms.

Pat Gerard, Pinellas County Commissioner, said their grant will focus on the Lealman community.

According to Gerard, that area lacks sidewalks, proper lighting, and smoothly paved roads.

"The Lealman community is a pretty big neighborhood," Gerard said. "There are about 40,000 people who live there but it's been pretty depressed and neglected for a long time."

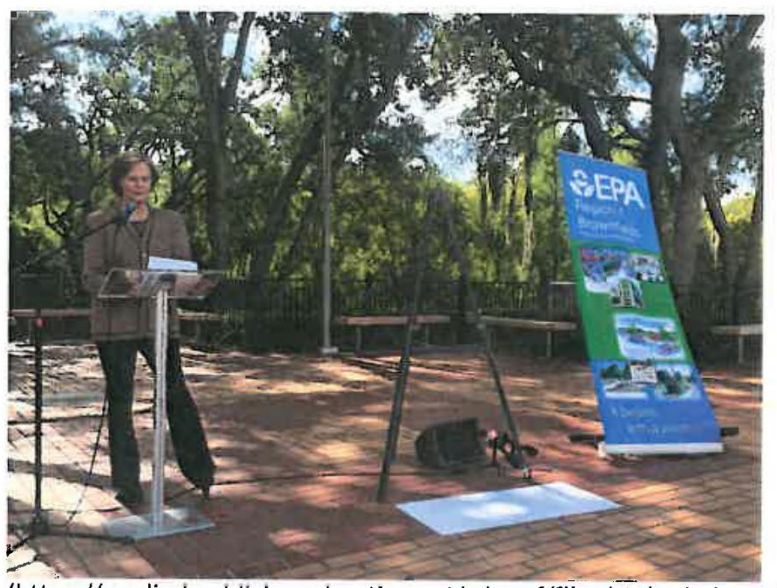

The three grants are called Brownsfield grants, which give money to cities to assess environmental risks and clean up any contaminants that are found.

They also encourage development in neglected areas - Rocco hopes the grant will bring "love, light, and hope" to the University Area community. 
Combs

\section{Exhibit 5: Initial Jobless Claims in Florida}

\section{Initial jobless claims in Florida}

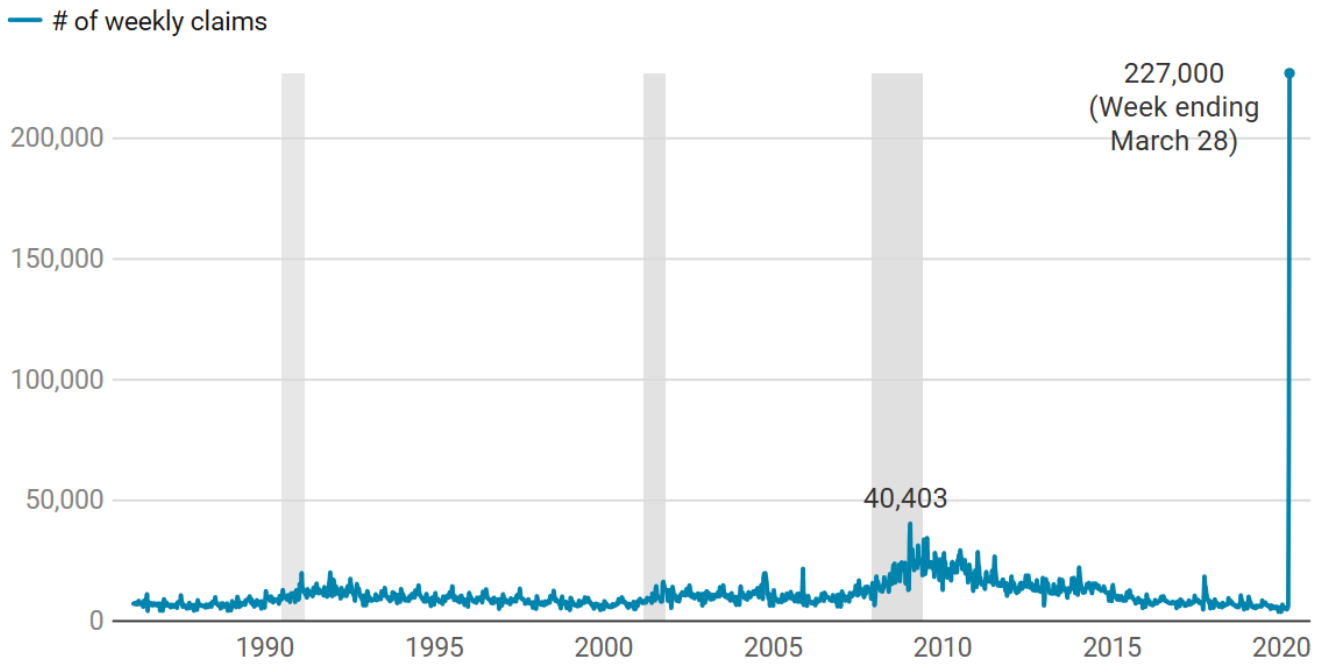

Shaded areas indicate U.S. recessions. Numbers aren't seasonally adjusted. Chart: Graham Brink • Source: U.S. Dept. of Labor · Created with Datawrapper 


\section{Exhibit 6: Senator Arthenia Joyner Article \& Photo}

\section{Long overdue library opens in University Area}

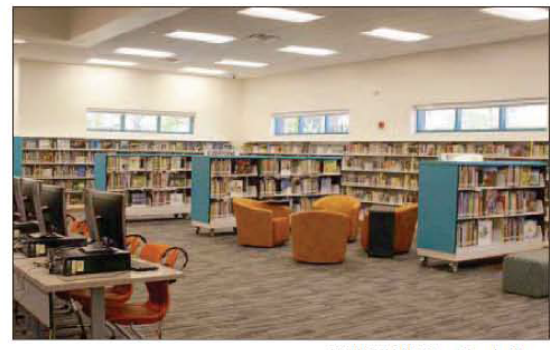

LENORA LAKE | Special to the
The Muller Elementary School media center is one side of the building that is the Arthenia L. Joyner University Area Community Library, 13619 N. 22nd St.

\section{) LIBRARY \\ continued from 1}

said.

Tina Russo, regional manager for the Tampa-Hillsborough County Public Library System, said: "This is different than the other partnership libraries
as they are not open to the public in the morning; they open at $2: 30$ p.m. This branch opens at $10 \mathrm{a} . \mathrm{m}$. and will be open all day long."

A wall with several double door separates the two but those door
A grand opening ceremony is set for the Arthenia L. Joyner library on N 22nd Street.

BY LENORA LAKE
Times Correspondent conceived in 1993 in a neighUNIVERSITY AREA - For adopted in the area's master more than 20 years, University plan in 1995, said Hillsborough Area residents have waited for County Commissioner Victor a library in their own neighbor- Crist, who has lead a community hood west of the University of South Florida.

Now the Arthenia L. Joyner University Area Community Library at $13619 \mathrm{~N} 22 n d$ St., will celebrate its grand opening ceremony Monday when government officials and others will speak at a free event, open to the public.
The idea of a library was first or take buses to libraries miles way in New Tampa or on North

"Now they can walk in here," the portation... so this is oweat" The library which cost more than $\$ 4.3$ million to build, is in than $\$ 4.3$ million to build, is in County Public Schools with one part the public library and the other the media center for Muller Elementary, which is next to the since its soft opening January, library.

munity for years.

Bill Harris, who has served

said the library was put on the "They (Muller and nearby county's "unfunded list" in 2002 Bowers/Whitley Career Center) and received funding in later waited 12 years for this library years. With its completion, area that they were promised," Crist residents no longer have to drive "See LIBRARY, 6
Tampa Bay Times North of Tampa Semi weekly 95,000 March 23, 2018

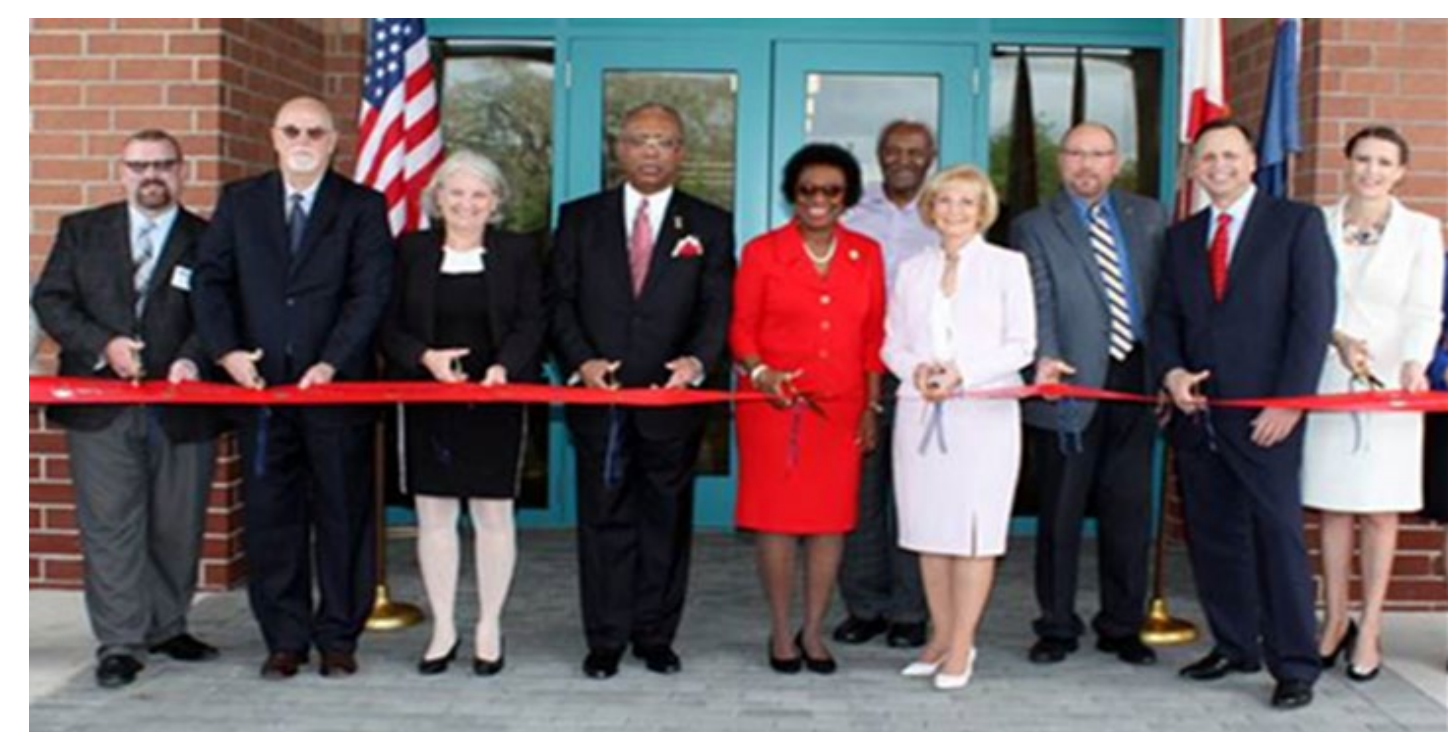

Left to Right: Andrew Breidenbaugh, Pastor Grantham, Commissioner Pat Kemp, Commissioner Les Miller, Senator Arthenia Joyner, Mr. Joyner, Commissioner Sandra Murman, Commissioner Victor Crist, Senator Tom Lee and Sarah Combs. 
Combs

\section{Exhibit 7: Florida Labor Market Statistics}

\section{Occupation Profile for Nursing Assistants in Hillsborough County, FL \\ Projected Annual Openings Table}

The table below shows the long term projected annual openings for Nursing Assistants in Workforce Region 15 CareerSource Tampa Bay, from 2015 to 2023.

\begin{tabular}{|l|r|r|r|}
\hline \multicolumn{1}{|c|}{ Occupation } & $\begin{array}{c}\text { Total Annual Average } \\
\text { Openings }\end{array}$ & $\begin{array}{c}\text { Annual Average Openings } \\
\text { Due to Growth }\end{array}$ & $\begin{array}{c}\text { Annual Average Openings Due to } \\
\text { Replacement }\end{array}$ \\
\hline $\begin{array}{l}\text { Nursing } \\
\text { Assistants }\end{array}$ & 254 & 150 & 104 \\
\hline $\begin{array}{l}\text { Healthcare } \\
\text { Support }\end{array}$ & 706 & 414 & \\
\hline
\end{tabular}

Source: Labor Market Statistics, Occupational Employment Projections Unit

Downloaded: 01/17/2019 2:06 PM

\section{Prior Employment Wage Statistics Table}

The table below shows the estimated employment wage statistics for individuals in Hillsborough County, FL employed for Nursing Assistants in 2015.

\begin{tabular}{|l|r|r|r|}
\hline \multicolumn{1}{|c|}{ Rate Type / Statistical Type } & Entry level & \multicolumn{1}{c|}{ Median } & Experienced \\
\hline Annual wage or salary & $\$ 20,713$ & $\$ 23,753$ & $\$ 26,843$ \\
\hline Hourly wage & $\$ 9.96$ & $\$ 11.42$ & $\$ 12.91$ \\
\hline
\end{tabular}

Source: FL Labor Market Statistics, Occupational Employment Statistics \& Wages Program

The median wage is the estimated 50 th percentile; 50 percent of workers in an occupation earn less than the median wage, and 50 percent earn more than the median wage. Entry level and Experienced wage rates represent the means of the lower $1 / 3$ and upper $2 / 3$ of the wage distribution, respectively. Data is from an annual survey. Downloaded: 01/17/2019 2:13 PM

\section{Occupation Profile for Landscaping and Groundskeeping Workers in Hillsborough County, FL}

\section{Projected Annual Openings Table}

The table below shows the long term projected annual openings for Landscaping and Groundskeeping Workers in Workforce Region 15 - CareerSource Tampa Bay, FL from 2015 to 2023.

\begin{tabular}{|l|r|r|r|}
\hline \multicolumn{1}{|c|}{ Occupation } & $\begin{array}{c}\text { Total Annual } \\
\text { Average Openings }\end{array}$ & $\begin{array}{c}\text { Annual Average } \\
\text { Openings Due to Growth }\end{array}$ & $\begin{array}{c}\text { Annual Average Openings } \\
\text { Due to Replacement }\end{array}$ \\
\hline $\begin{array}{l}\text { Landscaping and } \\
\text { Groundskeeping Workers }\end{array}$ & 267 & 111 & 156 \\
\hline
\end{tabular}

\section{Real Time Wage Rates on Advertised Jobs Table}

The table below shows a statistical breakdown of available wage data on the 33 job openings advertised online for Landscaping and Groundskeeping Workers in Hillsborough County, FL that posted a salary on January 16, 2019.
Rate Type / Statistical Type
Entry Level
Median
Experienced 
MUMA CASE REVIEW

\begin{tabular}{|l|r|r|r|}
\hline Annual wage or salary & $\$ 22,242$ & $\$ 26,836$ & $\$ 31,211$ \\
\hline Hourly Wage & $\$ 10.69$ & $\$ 12.90$ & $\$ 15.01$ \\
\hline
\end{tabular}

Source: Online advertised jobs data

Note: This information is based on actual job orders and is not based on a statistically valid labor market survey. Hourly wage rate calculations in this section assume a 40 hour work week.

Downloaded: 01/17/2019 2:15 PM

\section{Occupation Profile for Janitors and Cleaners, Except Maids and Housekeeping Cleaners in Hillsborough County, FL}

\section{Projected Annual Openings Table}

The table below shows the long term projected annual openings for Janitors and Cleaners, Except Maids and Housekeeping Cleaners in Workforce Region 15 - CareerSource Tampa Bay, FL from 2015 to 2023.

\begin{tabular}{|l|r|r|r|}
\hline \multicolumn{1}{|c|}{ Occupation } & $\begin{array}{c}\text { Total Annual } \\
\text { Average Openings }\end{array}$ & $\begin{array}{c}\text { Annual Average } \\
\text { Openings Due to } \\
\text { Growth }\end{array}$ & $\begin{array}{c}\text { Annual Average Openings } \\
\text { Due to Replacement }\end{array}$ \\
\hline $\begin{array}{l}\text { Janitors and Cleaners, Except } \\
\text { Maids and Housekeeping Cleaners }\end{array}$ & 312 & 150 & 162 \\
\hline $\begin{array}{l}\text { Building and Grounds Cleaning and } \\
\text { Maintenance }\end{array}$ & 848 & 388 & 460 \\
\hline
\end{tabular}

\section{Real Time Wage Rates on Advertised Jobs Table}

The table below shows a statistical breakdown of available wage data on the 124 job openings advertised online for Janitors and Cleaners, Except Maids and Housekeeping Cleaners in Hillsborough County, FL that posted a salary on January 16, 2019.

\begin{tabular}{|l|r|r|r|}
\hline \multicolumn{1}{|c|}{ Rate Type / Statistical Type } & \multicolumn{1}{c|}{ Entry Level } & \multicolumn{1}{c|}{ Median } & Experienced \\
\hline Annual wage or salary & $\$ 18,277$ & $\$ 20,800$ & $\$ 26,270$ \\
\hline Hourly Wage & $\$ 8.79$ & $\$ 10.00$ & $\$ 12.63$ \\
\hline
\end{tabular}

Source: Online advertised jobs data

Note: This information is based on actual job orders and is not based on a statistically valid labor market survey. Hourly wage rate calculations in this section assume a 40 hour work week.

Downloaded: 01/17/2019 2:16 PM 


\section{Exhibit 8: University Area CDC INVEST Workforce Model}

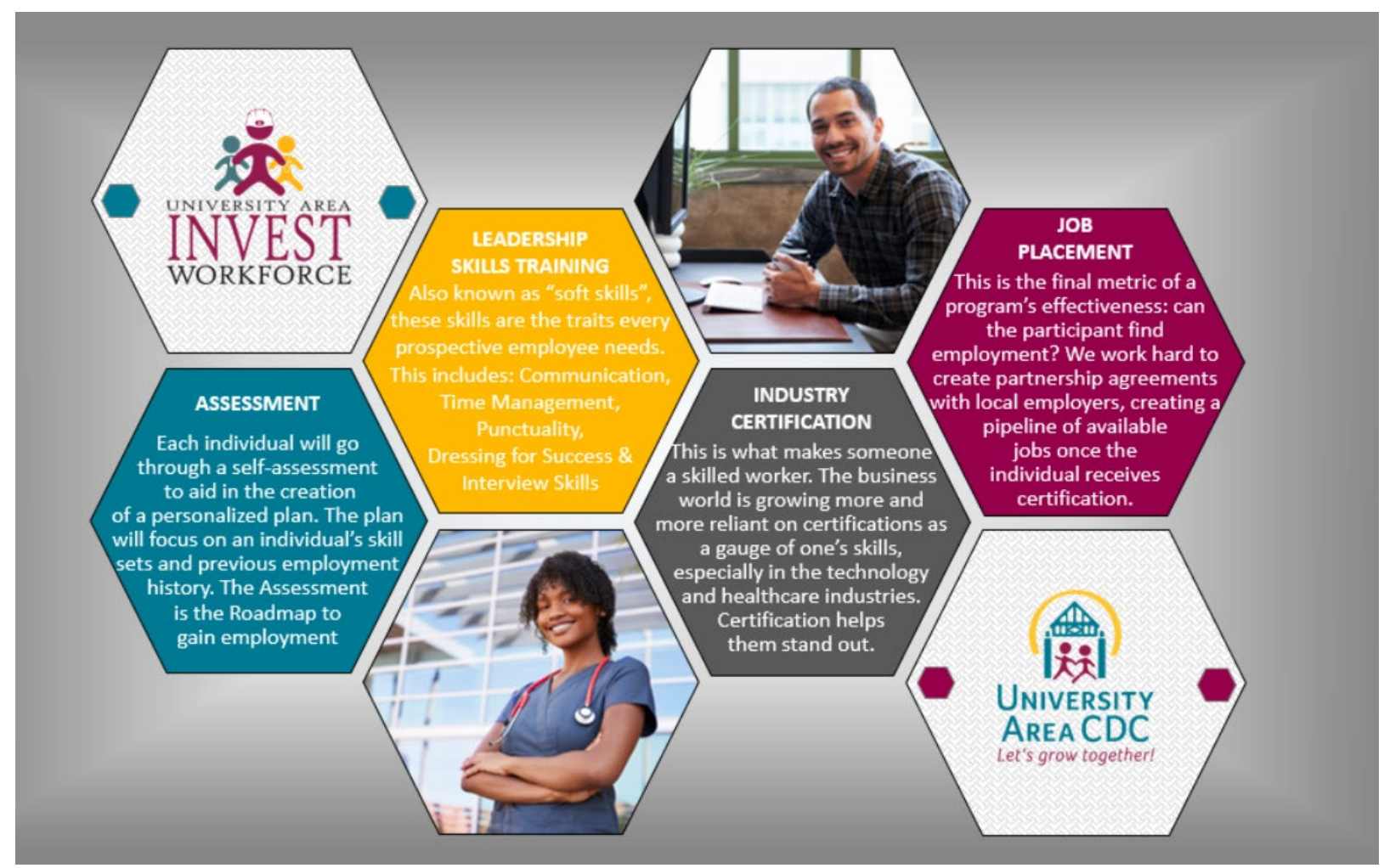

Source: University Area Community Development Corporation, Inc. Workforce INVEST program model 